\title{
Wasted talent is wasted opportunity
}

ThE Conservative and Unionist Party has been elected to govern the United Kingdom, with Mrs Thatcher as Prime Minister. The election was fought almost entirely on economic issues, and even on these the new government communicated little more than an intention. (We heard nothing about how much income tax would be cut, or what rise in value added tax would be necessary to pay for it, except for Labour's own, presumably biased, calculations.) Of science we have heard nothing-except on environmental issues from the Ecology Party, and on nuclear power from the Liberals.

We hope that the new government will recognise the central importance of science-and basic science, at thatto the economy. In oppositon, the Conservatives have frequently called attention to 'wealth creation', which it says Labour has ignored. The Conservatives appear prepared to increase social inequalities (by redistributing the tax burden) and risk confrontation with organised labour (by introducing new legislation and cutting 'lame duck' industrial support grants). But are they prepared to invest in science? It is undeniable that science is increasingly the true source of wealth, now that the days of empire and exploitation are receding. President Carter has recognised this, with his constant calls to Congress for an increase in science funding. And West Germany has recognised it, with a massive increase in funding for its science ministry in this year's budget.

Shirley Williams, the outgoing Secretary of State for Education and Science, had also recognised it, managing to wrest a few extra millions for the research councils this year. But will the Tories recognise it? We hope they will have the vision to do so, particularly with Britain's first scientist (Mrs Thatcher was a chemist) as Prime Minister. Mrs Williams' balm merely alleviated the worst of a long history of financial stringency in the research councils, and there is a great deal of slack to be taken up--not least in the replacement of aging equipment like spectrometers and microscopes, or proper investment in Britain's great scientific successes like molecular biology (where with genetic engineering there is enormous economic potential) or even the less obviously economic radio and high energy astronomy. Great international centres of excellence have a galvanising effect on the science of a country that goes far beyond their particular discipline. Even a geophysicist, for example, feels pride that the double helix was discovered in this country.

There is no doubt that science in the UK is depressed. This is the time to revitalise it. The argument that basic science should be left for better times is false. The country that now invests deeply in science, despite the state of the economy, will be the one that emerges from the present world recession ready to take the lead.

Furthermore, it's not just a question of money. If wealth creation is a matter of science (and its application through engineering), science is a matter of scientists. And Britain has never had a coherent policy for the growth and encouragement of its scientific community-just the usual British compromise of a decision here, a regulation there, a patchwork but no policy. The research councils have done their best to regulate and redirect studentships and fellowships; but they can only tinker with the problem. There is an enormous-perhaps 5,000-strong-and vital community of bright researchers locked into a cycle of frustrating and demoralising short-term contracts, produced by the unwritten policy of using an excessive number of research students as cheap labour and the static university system blocked with middle-young tenured staff. Of course 'the best' always get jobs-that's only a matter of circular definition. The real question is of the wasted talent, the real talent, that does not find effective employment, either in the universities or in industry.

This problem is not Britain's alone. Even Germany suffers from it, despite its enlightened attitude to science. But the country that breaks through the logjam first will have an immense advantage. We challenge the new government to find effective, creative employment for Britain's postdoctoral fellows. A dozen new whizz-kid centres of advanced study, some applied, some pure? A proper career structure for non-teaching researchers at universities and medical schools would be a good start. The objective must be to create new research schools, either attached to universities as non-teaching institutes or completely independent. Research doesn't grow at random. It depends on potentially creative branches having the opportunity to develop at the right moment. The United States took its great lead in science when Europe rejected its intellectuals during the time of Hitler; they landed in America and research communities spread rapidly around them.

US pre-eminence in theoretical sub-nuclear physics, for example, can be traced largely back to Enrico Fermi's school in Chicago. And how did Britain invent its way through the second world war? It gave men like R. V. Jones responsibility the moment they could shoulder it.

We should take exactly the same attitude to our postdoctoral community. It must be given the opportunity to spawn its own schools of research, in an atmosphere where there is-if not total job security-at least hope, and growth, and vision. The age of this community-reaching into the mid thirties - is just right to bear fruit. (Studies by Harriet Zuckerman, recorded in her book Scientific Elites (Free Press, New York: 1977), show that the average age at which Nobel prize-winners did their prize-winning work was around 36 . Those few who were under 30 were usually already members of flourishing research schools.)

So we say this to our new Prime Minister-whatever your successes or failures with industry and the more immediate problems of the nation: remember the scientists -and you will be remembered. 